\title{
THE EFFECT OF SELENIUM APPLICATION TO THE SOIL ON THE SULPHUR AND PHOSPHORUS CONTENT IN POTATOES
}

\author{
L. Zemková, J. Hlušek, T. Lošák, M. Jůzl, P. Elzner
}

Received: April 28, 2008

\begin{abstract}
ZEMKOVÁ, L'., HLUŠEK, J., LOŠÁK, T., JŮZL, M., ELZNER, P.: The effect of selenium application to the soil on the sulphur and phosphorus content in potatoes. Acta univ. agric. et silvic. Mendel. Brun., 2008, LVI, No. 5 , pp. 243-250

In a small-plot trial with potatoes were applied increasing doses of selenium to the soil $(0,12,24$, 48 and $72 \mathrm{~kg} \mathrm{Se} \cdot \mathrm{ha}^{-1}$ ) and after harvest were explored the content of selenium, phosphorus and sulphur in raw tubers and in the tops. The trials were conducted in two localities - Žabčice and Valečov using the semi-early variety Ditta. Selenium was applied to the soil in the form of sodium selenite before planting the potatoes. Chemical analyses discovered that with the applied dose the level of selenium increased in both tubers and tops and that the correlation between the applied selenium dose and its content in tubers and tops was significant $(\alpha<0.05)$ and positive $(r=0.885$ and $r=0.908$, respectively). With an increasing dose of selenium the reduction in the level of sulphur in the tops $(\mathrm{r}=$ $-0.872, \alpha<0.05$ ) was statistically significant. In both localities the range of the sulphur levels in tubers was very narrow, i.e. $0.16-0.18 \%$, and the effect of the selenium dose was not significant. The phosphorus content in tubers and tops did not change significantly after application of a dose of up to $48 \mathrm{~kg} \mathrm{Se} \cdot \mathrm{ha}^{-1}$. With the highest dose of selenium the content of phosphorus in both tops and tubers decreased significantly.
\end{abstract}

selenium, doses, potatoes, phosphorus, sulphur, interaction

Selenium is an essential element for humans and animals. Many studies have shown that the worldwide consumption of selenium is insufficient. Lyons et al. (2005a) proved that many South Australians consume inadequate amounts of Se to maximise selenoenzyme expression and cancer protection. Deprivation of Se is associated with impaired antioxidant protection (Combs, 2001). Clark et al. (1996) detected that patients treated with Se had significant reductions in total cancer incidence and in total cancer mortality. Most papers published in China focused on the relationship between environmental Se deficiency and Keshan Disease and reported that the incidence of Keshan Disease is closely associated with very low dietary intake of Se (Fang et al., 2002; Tan et al., 2002; Ge and Yang, 1993). Reilly (1998) mentioned other diseases related with Se deficiency and remarked that dietary intake of Se in the UK is reduced. Lintschinger et al. (2000) mentioned that Se supply in Austria and Germany is below the re- commended daily intake as well. Data determined by Kvíčala et al. (1995) showed that the Czech Republic belongs among the countries with low Se intake.

Agronomic fortification offers an effective strategy to increase the Se content in plant production. Applying Se-enriched fertilizers to crops is an effective preventive technique against the Keshan Disease in children in China (Fang et al., 2002). Broadley et al. (2006) mentioned that Se intake in the UK population can be increased in the short term through agronomic biofortification. In Finland all agricultural multinutrient fertilisers have been supplemented with Se since 1984 in order to increase the Se content in domestic foods and to raise the dietary Se intake of consumers (Eurola et al., 1991). Many studies showed that Se application enhanced the Se content in plants. For their trials Liu et al. (2004) used rice, El Ghanam (2004) soybean plants, Vinay-Singh and Malik (1990) berseem, Lyons et al. (2005b) and Ducsay and Ložek (2006) wheat, Kopsell and Randle 
(1997) and Barak and Goldman (1997) onion, Toler et al. (2007) Brassica oleracea, Munshi and Mondy (1992) and Poggi et al. (2000) potatoes. Lintschinger et al. (2000) showed that a significant accumulation of Se was possible in wheat, alfalfa and sunflower seeds during sprouting in a solution containing Se and that these sprouts might provide the starting material for fortified cereal-based diets.

An interaction between selenium and some of the elements is expected. The chemical and physical properties of selenium are very similar to those of sulphur (Barker and Pilbeam, 2007; Kabata-Pendias and Pendias, 2000; Reilly, 1998). Increasing levels of selenium in plants may suppress the tissue concentrations of nitrogen, phosphorus and sulphur. It can also inhibit the absorption of heavy metals (KabataPendias and Pendias, 2000). Vinay-Singh and Malik (1990) detected that applied Se decreased P and S uptake. Furthermore, absorption and utilisation of Se decreased in the presence of $S$ and P. Kopsell et al. (2000) proved that Se enrichment decreased the P content in leaf tissue, but the $S$ content increased with increasing Se treatment. In another study, a low concentration of Se enhanced S uptake and accumulation as well (Kopsell and Randle, 1997). Li and Zhu (2007) found that the S content in shoots was not influenced by added Se concentration, but that the Se content in shoots considerably decreased by increasing the S supply. In another study (Barak and Goldman, 1997) discovered that an addition of Se to the solution culture reduced S uptake by the plant, and Se uptake was suppressed by increasing the S concentration in solution culture. That indicated a competitive relationship between these two elements.

On the contrary, a synergistic interaction between Se and S was reported by Rani et al. (2005), Mikkelsen (1988), Mikkelsen and Wan (1990), White et al. (2004), Toler et al. (2007), Charron et al. (2001). Lyons et al. (2005b) confirmed these results but remarked that a high concentration of Se in the soil may inhibit $S$ transport.

A few authors investigated the relationship between selenium and phosphorus. Although mutual interaction is not expected, interesting results were achieved. The interaction between selenium and phosphorus was evident (Liu et al., 2004). He et al. (1994) found out that applied P decreased selenite sorption by ryegrass and that $\mathrm{P}$ sorption decreased with an increasing concentration of Se in the initial solution. El Ghanam (2004) found that P uptake by soybeans was significantly but negatively affected by increasing levels of applied Se. Li et al. (2008) studied the effect of $\mathrm{P}$ starvation on Se uptake in a hydroponics experiment. They found that $\mathrm{P}$ starvation increased Se uptake and suggested that P competitively inhibited Se absorption by the wheat root. Rani et al. (2005) found that the application of Se had no significant effect on the P content of different crops maize, wheat and rice, except the raya crop.

In the present study we applied different doses of selenium into the soil and compared the selenium content in tubers and tops. The next objective was to explore the possible effect of supplied selenium on the content of sulphur and phosphorus in potato tops and tubers. In our experiment we used potatoes because they are an important component of the human diet in the Czech Republic.

\section{MATERIAL AND METHODS}

The field experiments were conducted in two localities in the Czech Republic - Valečov (460 meters above sea level) and Žabčice (184 meters above sea level) in 2006. The important agrochemical characteristics of soils are shown in Tab. I. Soil samples were analysed according to Mehlich III $\left(\mathrm{CH}_{3} \mathrm{COOH}\right.$, $\mathrm{NH}_{4} \mathrm{NO}_{3}, \mathrm{NH}_{4} \mathrm{~F}, \mathrm{HNO}_{3}$ and EDTA). The content of phosphorus was determined by UV-vis spectrophotometry, potassium by atomic emission spectrometry, magnesium and calcium by atomic absorption spectrometry. The content of selenium was determined by atomic absorption spectrometry in an extract of $2 \mathrm{M} \mathrm{HNO}_{3}$.

I: Agrochemical characteristics of the soil $\left(\mathrm{mg}^{\mathrm{kg}} \mathrm{kg}^{-1}\right)$ in two localities

\begin{tabular}{|l|c|c|}
\hline & Žabčice & Valečov \\
\hline $\mathrm{pH} / \mathrm{CaCl}_{2}$ & 6.64 & 6.20 \\
\hline $\mathrm{P}$ & 112 & 353 \\
\hline $\mathrm{K}$ & 240 & 318 \\
\hline $\mathrm{Mg}$ & 311 & 74 \\
\hline $\mathrm{Ca}$ & 4499 & 2036 \\
\hline $\mathrm{Se}$ & 0.10 & 0.34 \\
\hline
\end{tabular}

Selenium was applied as sodium selenite to the soil at the following rates: 0, 12, 24, 48 and $72 \mathrm{~kg}$ Se.ha-1. Range of Se-doses was proposed to detect and emphasize potential differences between smaller and higher doses of selenium on the studied characteristics. Therefore in the trial were used high doses of selenium - 48 and $72 \mathrm{~kg} \mathrm{Se} \cdot \mathrm{ha}^{-1}$, but this amount is not used in agricultural practise. The experiments were established in four replications and the semiearly variety Ditta was used for the trials. The potatoes (Solanum tuberosum) were planted in April/May, spacing was $750 \times 250 \mathrm{~mm}$ and the size of one plot was $20.25 \mathrm{~m}^{2}$. Selenium was applied in the form of a sodium selenite solution on the soil surface two days before planting and then selenium was mixed with the topsoil during soil preparation. Samples for chemical analyses were collected at the time of consumer ripeness, in this case after 99 days of vegetation. The tops were washed, dried at $60^{\circ} \mathrm{C}$ in the laboratory drier and homogenized in the laboratory grinder. The samples of tubers were washed, peeled, cut and after drying the samples were homogenized. After preparation the samples were mineralized in a mixture of $\mathrm{HNO}_{3}$ and $\mathrm{H}_{2} \mathrm{O}_{2}$ in the microwave system. After decomposition the content of selenium was analysed by atomic absorption spectrometry 
and sulphur and phosphorus by inductively coupled plasma optical emission spectrometry (ICP-OES). The data were statistically analysed using the software STATISTICA 7.0. Subsequent tests of the differences were performs according to Tuckey‘s test.

\section{RESULTS AND DISCUSSION}

Applications of selenium dose ranging from 0 to $72 \mathrm{~kg}$ Se.ha ${ }^{-1}$ increased the selenium content in the studied samples; in potato tubers in the Žabčice and Valečov localities by $0.33-4.40 \mathrm{mg}$ Se. $\mathrm{kg}^{-1} \mathrm{DM}$ and $0.74-4.08 \mathrm{mg}$ Se. $\mathrm{kg}^{-1} \mathrm{DM}$, respectively, and in potato tops it increased from 0.40 to
$6.45 \mathrm{mg}$ Se. $\mathrm{kg}^{-1} \mathrm{DM}$ and from 0.82 to as much as $6.30 \mathrm{mg}$ Se. $\mathrm{kg}^{-1} \mathrm{DM}$ respectively in the Žabčice and Valečov localities. Tab. II shows the significant differences among the respective treatment variants. A highly significant positive correlation was discovered between the applied Se dose and the Se content in both potato tubers $(\mathrm{r}=0.885)$ and tops $(\mathrm{r}=0.908)$ at $\alpha<0.05$. When we compared the analysed parts, i.e. tubers and tops, we detected a higher content of selenium in the tops. The higher content of Se in samples of the variant not treated with selenium in the Valečov locality was probably caused by the higher content of Se in the soil $\left(0.34 \mathrm{mg}\right.$. $\mathrm{kg}^{-1}$ of soil, as compared to $0.1 \mathrm{mg} \cdot \mathrm{kg}^{-1}$ of soil in the Žabčice locality.

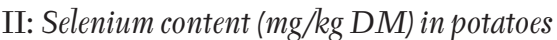

\begin{tabular}{|c|c|c|c|c|}
\hline \multirow{2}{*}{ Dose of Se $\left(\mathrm{kg}^{*} \mathrm{ha}^{-1}\right)$} & \multicolumn{2}{|c|}{ Žabčice } & \multicolumn{2}{c|}{ Valečov } \\
\cline { 2 - 5 } & Tubers & Tops & Tubers & $0.82 \mathrm{a}$ \\
\hline 0 & $0.33 \mathrm{a}$ & $0.40 \mathrm{a}$ & $1.50 \mathrm{ab}$ & $2.78 \mathrm{~b}$ \\
\hline 12 & $1.60 \mathrm{ab}$ & $1.45 \mathrm{a}$ & $2.47 \mathrm{bc}$ & $3.95 \mathrm{bc}$ \\
\hline 24 & $2.74 \mathrm{bc}$ & $4.68 \mathrm{~b}$ & $3.82 \mathrm{~cd}$ & $5.06 \mathrm{~cd}$ \\
\hline 48 & $3.35 \mathrm{~cd}$ & $5.54 \mathrm{bc}$ & $4.08 \mathrm{~d}$ & $6.30 \mathrm{~d}$ \\
\hline 72 & $4.40 \mathrm{~d}$ & $6.45 \mathrm{c}$ & $\mathrm{c}$ & \\
\hline
\end{tabular}

$\mathrm{a}, \mathrm{b}, \mathrm{c}, \mathrm{d}$ average values indicated with different letters are significantly different $(\alpha<0.05)$

Li and Zhu (2007) also discovered that after the applications of increasing doses of selenium the Se content in the plant increased statistically significantly. Kopsell et al. (2000), Kopsell and Randle (1997), El Ghanam (2004), Liu et al. (2004) and White et al. (2004) achieved the same results. Also Vinay-Singh and Malik (1990) confirmed that the content of Se increased in Trifolium alexandrinum after soil application of 0 to 20 ppm Se. Rani et al. (2005) applied various doses of selenium ranging between 0 and $25 \mu \mathrm{g}$. $\mathrm{g}^{-1}$ to the soil and in different crops they achieved a multiple increase in the Se content. Lyons et al. (2005a) applied selenium in the form of sodium selenate in doses ranging from 4 to $120 \mathrm{~g}$ Se.ha- ${ }^{-1}$ and discovered as much as a 133-fold increase in the concentration of selenium in wheat; they recommend biofortification as an effective method of production of wheat which has a favourable effect on the health of the population. Munshi and Mondy (1992) applied sodium selenite in doses ranging between 0 and $5.6 \mathrm{~kg} \cdot \mathrm{ha}^{-1}$ and discovered a considerable increase in the selenium level in potato tubers. After the application of 0 to $72 \mathrm{~kg}$ Se.ha-1 Hlušek et al. (2005) also discovered a higher Se content in potato tubers, i.e.

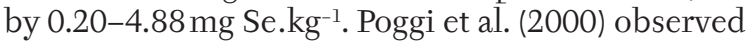
linear increase $(r=0.949)$ in the concentrations of selenium in tubers after increasing doses of foliar applications of selenium. Ducsay and Ložek (2006) also used the foliar applications to wheat; an application of $20 \mathrm{~g} \mathrm{Se} \cdot \mathrm{ha}^{-1}$ increased the selenium content from 0.045 to $0.145 \mathrm{mg}$ Se. $\mathrm{kg}^{-1}$.
The content of sulphur in potatoes was also monitored after the soil application of selenium. The content of sulphur in potato tops was found to be statistically significantly influenced by the applied selenium dose $(\alpha<0.05)$. Tab. III shows the significant differences among the treatments of selenium fertilisation; with increasing doses of selenium in the soil the sulphur content in potato tops significantly decreased. The correlation coefficient equals $r=-0.872$ at a level of significance of $\alpha<0.05$. In the Se-untreated variant the sulphur content in the tops was $0.48 \%$ and $0.49 \%$ in Žabčice and Valečov, respectively. In the treatment where $72 \mathrm{~kg}$ Se.ha-1 was applied it decreased to $0.26 \%$ and $0.29 \%$, respectively. A statistically significant effect of the applied dose of selenium on the sulphur content was monitored in potato tubers in the Žabčice locality. After the application of the highest dose of selenium to the soil the sulphur content in tubers decreased significantly, i.e. to $0.16 \%$ compared to $0.17-0.18 \%$ in the other variants. In the Valečov locality this trend was not confirmed although the range of the sulphur contents was identical, i.e. $0.16-0.18 \%$ of sulphur. At the same time no statistically significant correlation was detected between the applied Se dose and S content in potato tubers.

The decrease in the sulphur content in potato tops with increasing selenium doses seen in our experiment is in accordance with Vinay-Singh and Malik (1990), Kabata-Pendias and Pendias (2000) who alleged that the application of selenium reduced plant uptake of sulphur. Also Barak and Goldman 
(1997) proved that an addition of Se to a culture solution at a constant level of $S$ reduced $S$ uptake which dropped from $5.1 \mathrm{mg} /$ plant at 1 g. $\mathrm{m}^{-3}$ Se-treatment to $1.2 \mathrm{mg} /$ plant at $8 \mathrm{~g} . \mathrm{m}^{-3}$ Se-treatment. By contrast our results are at variance with Kopsell et al. (2000) who indicated that the sulphur content in rape leaves increased with increasing doses of applied selenium. Mikkelsen (1988) also discovered a synergistic effect between Se and S. Tissue S increased from less

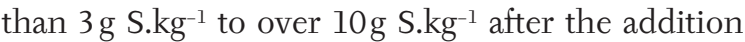
of $1 \mathrm{mg} \mathrm{Se.}{ }^{-1}$. The conclusions of Toler et al. (2007) showed that Se concentration in the nutrient solution was positively correlated with $S$ uptake in the plants. The content of $S$ in Brassica oleracea leaves increased from $1.2 \%$ to $1.8 \%$. Similarly White et al. (2004) discovered a statistically significant increase of the $S$ content in the model plant Arabidopsis thaliana with an increasing Se content in the growth agar, but this does not correspond with our results. Rani et al. (2005) proved that the sulphur content of different plant tissues increased with the application of Se and significant positive correlation coefficient values were recorded between the Se and S content in plants. This is at variance with our results. Lyons et al. (2005b) reported an increasing concen- tration of sulphur with increasing doses of selenium in wheat leaves. However, they pointed out that doses of more than $40 \mathrm{mg} \mathrm{Se} . \mathrm{kg}^{-1}$ might inhibit sulphur uptake. Conclusions of Li and Zhu (2007) indicated that the sulphur content in the plant was not influenced by the application of selenium; this corresponds with our results observed in potato tubers in the Valečov locality.

Tab. IV shows the content of phosphorus in potato tubers and tops in both localities. Compared to the control treatment the phosphorus content in tubers supplied with the highest dose of selenium in the soil decreased statistically significantly on both localities (Tab. IV). There was no difference in the phosphorus content among the other treatments. In the Žabčice locality the phosphorus content in the tops fluctuated within a narrow range of $0.14-0.18 \%$ and in the Valečov locality between $0.16-0.21 \%$. Selenium doses affected the phosphorus content in both tops and tubers. Likewise a statistically significant negative correlation was discovered between the applied Se dose and $\mathrm{P}$ content in potato tubers $(r=-0.688)$ and tops $(r=-0.569)$ at $\alpha<$ 0.05 .

III: The sulphur content (\% DM) in potatoes

\begin{tabular}{|c|c|c|c|c|}
\hline \multirow{2}{*}{ Dose of Se $\left(\mathrm{kg}^{*} \mathrm{ha}^{-1}\right)$} & \multicolumn{2}{|c|}{ Žabčice } & \multicolumn{2}{c|}{ Valečov } \\
\cline { 2 - 5 } & Tubers & Tops & Tubers & Tops \\
\hline 0 & $0.18 \mathrm{c}$ & $0.48 \mathrm{~d}$ & $0.17 \mathrm{a}$ & $0.49 \mathrm{c}$ \\
\hline 12 & $0.18 \mathrm{bc}$ & $0.38 \mathrm{bc}$ & $0.18 \mathrm{a}$ & $0.42 \mathrm{bc}$ \\
\hline 24 & $0.16 \mathrm{ab}$ & $0.41 \mathrm{~cd}$ & $0.16 \mathrm{a}$ & $0.39 \mathrm{~b}$ \\
\hline 48 & $0.17 \mathrm{bc}$ & $0.33 \mathrm{ab}$ & $0.18 \mathrm{a}$ & $0.35 \mathrm{ab}$ \\
\hline 72 & $0.16 \mathrm{a}$ & $0.26 \mathrm{a}$ & $0.17 \mathrm{a}$ & $0.29 \mathrm{a}$ \\
\hline
\end{tabular}

$\mathrm{a}, \mathrm{b}, \mathrm{c}, \mathrm{d}$ average values indicated with different letters are significantly different $(\alpha<0.05)$

IV: The phosphorus content (\% DM) in potatoes

\begin{tabular}{|c|c|c|c|c|}
\hline \multirow{2}{*}{ Dose of Se $\left(\mathrm{kg}^{*} \cdot \mathrm{ha}^{-1}\right)$} & \multicolumn{2}{|c|}{ Žabčice } & \multicolumn{2}{c|}{ Valečov } \\
\cline { 2 - 5 } & Tubers & Tops & Tubers & Tops \\
\hline 0 & $0.27 \mathrm{~b}$ & $0.18 \mathrm{~b}$ & $0.31 \mathrm{~b}$ & $0.19 \mathrm{ab}$ \\
\hline 12 & $0.28 \mathrm{~b}$ & $0.18 \mathrm{ab}$ & $0.31 \mathrm{~b}$ & $0.21 \mathrm{~b}$ \\
\hline 24 & $0.26 \mathrm{~b}$ & $0.18 \mathrm{~b}$ & $0.30 \mathrm{ab}$ & $0.21 \mathrm{~b}$ \\
\hline 48 & $0.25 \mathrm{~b}$ & $0.15 \mathrm{ab}$ & $0.26 \mathrm{ab}$ & $0.17 \mathrm{ab}$ \\
\hline 72 & $0.20 \mathrm{a}$ & $0.14 \mathrm{a}$ & $0.24 \mathrm{a}$ & $0.16 \mathrm{a}$ \\
\hline
\end{tabular}

a, b average values indicated with different letters are significantly different $(\alpha<0.05)$

Results publishedbyVinay-SinghandMalik(1990), Kopsell et al. (2000) and He et al. (1994) showed that the phosphorus content in plants decreased with increasing selenium treatments. This corresponds with our results saying that with higher doses of selenium the phosphorus content decreased in both tops and tubers. El Ghanam (2004) found that P uptake was significantly, but negatively, affected by increasing levels of applied Se; this corresponds with our results. However, the conclusions of Rani et al. (2005) are at variance with our findings. They observed that the application of Se did not have a significant effect on the $\mathrm{P}$ content in wheat, rice and maize. 


\section{SUMMARY}

In a small-plot trial with potatoes were applied increasing doses of selenium to the soil and after harvest were determined the content of selenium, phosphorus and sulphur in raw tubers and in the tops. The trials were conducted in two localities - Žabčice and Valečov using the semi-early variety Ditta. Selenium was applied to the soil in the form of sodium selenite at the following rates: 0, 12, 24, 48 and $72 \mathrm{~kg} \mathrm{Se} . \mathrm{ha}^{-1}$. Samples for chemical analyses were collected after 99 days of vegetation. The applied dose of selenium increased the content of selenium in both tubers and tops and the correlation between the applied selenium dose and its content in tubers and tops $(r=0.885$ and $r=0.908$, respectively) was significant $(\alpha<0.05)$ and positive. After comparison of analysed parts, i.e. tubers and tops, a higher content of selenium was detected in the tops. The next objective of trial was to find out the effect of applied selenium on the content of sulphur and phosphorus in potato tops and tubers. With an increasing dose of selenium the reduction in the sulphur content in the tops was statistically significant $(r=-0.872, \alpha<0.05)$. In the Se-untreated variant the sulphur content in the tops was $0.48 \%$ and $0.49 \%$ in Žabčice and Valečov. In the treatment with the highest dose of selenium the sulphur content decreased to $0.26 \%$ and $0.29 \%$, respectively. In both localities the range of the sulphur levels in tubers was very narrow, i.e. $0.16-0.18 \%$. Compared to the control treatment the phosphorus content in tubers and tops supplied with the highest dose of selenium in the soil decreased statistically significantly, but the phosphorus content did not change significantly after application of a dose of up to $48 \mathrm{~kg} \mathrm{Se}$. ha ${ }^{-1}$. The results show that targeted soil supplementation of selenium can increase its content in potato plants and that as an important part of the population diet may ensure higher selenium uptake. It was also proved that selenium may affect the content of phosphorus and sulphur in the plant.

\section{SOUHRN}

Ovlivnění obsahu síry a fosforu u brambor po aplikaci selenu do půdy

V maloparcelkovém pokusu s bramborami byly aplikovány zvyšující se dávky selenu do půdy a po sklizni byl sledován obsah selenu, fosforu a síry v syrových hlízách a v nati brambor. Ke sledování byla použita poloraná odrůda Ditta a pokus byl prováděn na dvou lokalitách - Žabčice a Valečov. Selen byl aplikován ve formě seleničitanu sodného do půdy před výsadbou brambor v dávkách $0,12,24,48$ a 72 kg Se.ha ${ }^{-1}$. Odběr vzorků brambor byl proveden po 99 dnech vegetace. Z chemických analýz byl zjištěn nárůst obsahu selenu v hlízách i v nati brambor $s$ jeho aplikovanou dávkou a rovněž průkazná $(\alpha<0,05)$ pozitivní korelace mezi aplikovanou dávkou selenu a jeho obsahem vhlízách $(\mathrm{r}=0,885)$ a v nati brambor $(\mathrm{r}=0,908)$. Porovnáním analyzovaných částí, t.j. hlízy a nat', byl zaznamenán vyčší obsah selenu v nati brambor. Dále byl v pokusu sledován vliv aplikace selenu na obsah síry a fosforu v nati a v hlízách brambor. Bylo prokázáno statisticky významné snížení obsahu síry v nati brambor $(\mathrm{r}=-0,872, \alpha<0,05)$ s narůstající dávkou selenu. Obsah síry v nati byl u kontrolní varianty bez aplikace selenu 0,48\% v lokalitě Žabčice a 0,49\% v lokalitě Valečov a u varianty s nejvyšší dávkou selenu obsah síry klesal v obou lokalitách na 0,26\% a 0,29\%. Obsah síry v hlízách byl na obou lokalitách v úzkém rozpětí 0,16-0,18\%. Při hodnocení obsahu fosforu v rostlině byl zaznamenán statisticky průkazný pokles obsahu fosforu v hlízách a v nati brambor při aplikaci dávky $72 \mathrm{~kg}$ Se.ha-1 v porovnání $s$ variantou bez aplikace selenu, ale obsah fosforu se signifikantně neměnil při aplikaci dávek do $48 \mathrm{~kg} \mathrm{Se} \cdot h a^{-1}$.Ze zjištěných výsledků je zřejmé, že cílenou suplementací selenu do půdy je možné navýšit jeho obsah v rostlinách brambor, a tím zajistit vyšší př́ijem selenu u obyvatelstva. Bylo také zjištěno, že aplikace selenu ovlivňuje obsah fosforu a síry v rostlině.

selen, dávky, brambory, fosfor, síra, interakce

\section{ACKNOWLEDGEMENTS}

The present study is a part of the project of NAZV No. 1G46058 called "Strengthening the competitive ability of potato producers growing tubers of higher consumer quality".

This study was supported by the Research Plan No. MSM6215648905 "Biological and technological aspects of sustainability of controlled ecosystems and their adaptability to climate change", which is financed by the Ministry of Education, Youth and Sports of the Czech Republic.

\section{REFERENCES}

BARAK, P., GOLDMAN, I. L., 1997: Antagonistic relationship between selenate and sulfate uptake in onion (Allium cepa): implications for the production of organosulfur and organoselenium compounds in plants. Journal of Agricultural and Food Chemistry, 45, 4: 1290-1294. ISSN 0021-8561.

BARKER, A. V., PILBEAM, D. J., 2007: Handbook of Plant Nutrition. Boca Raton: Taylor and Francis, 613 s. ISBN 0-8247-5904-4. 
BROADLEY, M. R., WHITE, P. J., BRYSON, R. J., MEACHAM, M. C., BOWEN, H. C., JOHNSON, S. E., HAWKESFORD, M. J., McGRATH, S. P., ZHAO, F. J., BREWARD, N., HARRIMAN, M., TUCKER, M., 2006: Biofortification of UK food crops with selenium. Proceedings of the Nutrition Society, 65, 2: 169-181. ISSN 0029-6651.

CLARK, L. C., COMBS, G. F. Jr., TURNBULL, B. W., SLATE, E. H., CHALKER, D. K., CHOW, J., DAVIS, L. S., GLOVER, R. A., GRAHAM, G. F., GROSS, E. G., KRONGRAD, A., LESHER, J. L. Jr., PARK, H. K., SANDERS, B. B. Jr., SMITH, C. L., TAYLOR, J. R., 1996: Effects of selenium supplementation for cancer prevention in patients with carcinoma of the skin: A randomized controlled trial. Journal of the American Medical Association, 276, 24: 1957-1963. ISSN 0098-7484.

COMBS, G. F. Jr., 2001: Selenium in global food systems. British Journal of Nutrition, 85, 5: 517-547. ISSN 0007-1145.

DUCSAY, L., LOŽEK, O., 2006: Effect of selenium foliar application on its content in winter wheat grain. Plant, Soil and Environment, 52, 2: 78-82. ISSN 1214-1178.

EL GHANAM, M. M. M., 2004: Interaction effect between phosphorus and selenium on their availability in soil and contents in soybean plants grown on alluvial clayey soil. Annals of Agricultural ScienceMoshtohor, 42, 4: 2075-2088. ISSN 1110-0419.

EUROLA, M. H., EKHOLM, P. I., YLINEN, M. E., KOIVISTOINEN, P. E., VARO, P. T., 1991: Selenium in Finnish foods after beginning the use of selenate-supplemented fertilizers. Journal of the Science of Food and Agriculture, 56, 1: 57-70. ISSN 0022-5142.

FANG, W., WU, P., HU, R., 2002: Environmental SeMo-B deficiency and its possible effects in Jiantou Keshan disease area in Shaanxi Province, China. Environmental Geochemistry and Health, 24, 4: 349-358. ISSN 0269-4042.

GE, K., YANG, G., 1993: The epidemiology of selenium deficiency in the etiological study of endemic diseases in China. American Journal of Clinical Nutrition, 57, 2: 259-263. ISSN 0002-9165.

HE, Z. L., YANG, X. E., ZHU, Z. X., ZHANG, Q. Z., XIA, W. P., TAN, J. A., 1994: Effect of phosphate on the sorption, desorption and plant-availability of selenium in soil. Fertilizer Research, 39, 3: 189-197. ISSN 0167-1731.

HLUŠEK, J., JƯZL, M., ČEPL, J., LOŠÁK T., 2005: Effect of selenium supplementation on its concentration in potato tubers. Chemické Listy, 99, 7: 515-517. ISSN 0009-2770.

CHARRON, C. S., KOPSELL, D. A., RANDLE, W. M., SAMS, C. E., 2001: Sodium selenate fertilisation increases selenium accumulation and decreases glucosinolate concentration in rapid-cycling Brassica oleracea. Journal of the Science of Food and Agriculture, 81, 9: 962-966. ISSN 0022-5142.

KABATA-PENDIAS, A., PENDIAS, H., 2000: Trace elements in soils and plants. 3rd edition. Boca Raton: CRC Press, 413 s. ISBN: 0-8493-1575-1.
KOPSELL, D. A., RANDLE, W. M., 1997: Selenate concentration affects selenium and sulfur uptake and accumulation by ,Granex 33' onions. Journal of the American Society for Horticultural Science, 122, 5: 721-726.0003-1062.

KOPSELL, D. A., RANDLE, W. M., MILLS, H. A., 2000: Nutrient accumulation in leaf tissue of rapid-cycling Brassica oleracea responds to increasing sodium selenate concentrations. Journal of Plant Nutrition, 23, 7: 927-935. ISSN 0190-4167.

KVIIČALA, J., ZAMRAZIL, V., ČEROVSKÁ, J., BEDNÁŘ, J., JANDA, J., 1995: Evaluation of selenium supply and status of inhabitants in three selected rural and urban regions of the Czech Republic. Biological Trace Element Research, 47, 1-3: 365-375. ISSN 0163-4984.

LI, H. F., McGRATH, S. P., ZHAO, F. J., 2008: Selenium uptake, translocation and speciation in wheat supplied with selenate or selenite. New Phytologist, 178, 1: 92-102. ISSN 0028-646X.

LI, J., ZHU, Z. J., 2007: Effects of selenium and sulfur treatments on nutritional quality and antioxidant substances of leaf mustard. Journal of Zhejiang University Agriculture and Life Sciences, 33, 5: 539-543. ISSN 1008-9209.

LINTSCHINGER, J., FUCHS, N., MOSER, J., KUEHNELT, D., GOESSLER, W., 2000: Selenium-enriched sprouts. A raw material for fortified cerealbased diets. Journal of Agricultural and Food Chemistry, 48, 11: 5362-5368. ISSN 0021-8561.

LIU, Q., WANG, D. J., JIANG, X. J., CAO, Z. H., 2004: Effects of the interactions between selenium and phosphorus on the growth and selenium accumulation in rice (Oryza sativa). Environmental Geochemistry and Health, 26, 2-3: 325-330. ISSN 0269-4042.

LYONS, G.H., JUDSON, G. J., ORTIZ, M.I., GENC, Y., STANGOULIS, J. C. R., GRAHAM, R. D., 2005a: Selenium in Australia: Selenium status and biofortification of wheat for better health. Journal of Trace Elements in Medicine and Biology, 19, 1: 75-82. ISSN 0946-672X.

LYONS, G. H., STANGOULIS, J. C. R., GRAHAM, R. D., 2005b: Tolerance of wheat (Triticum aestium L.) to high soil and solution selenium levels. Plant and Soil, 270: 179-188. ISSN 0032-079X.

MIKKELSEN, R. L., 1988: The Influence of Selenium, Salinity, and Boron on Alfalfa Tissue Composition and Yield. Journal of Environmental Quality, 17, 85-88.

MIKKELSEN, R. L., WAN, H. F., 1990: The effect of selenium on sulfur uptake by barley and rice. Plant and Soil, 121, 1: 151-153. ISSN 0032-079X.

MUNSHI, C. B., MONDY, N. I., 1992: Glycoalkaloid and nitrate content of potatoes as affected by method of selenium application. Biological Trace Element Research, 33, 121-127. ISSN 0163-4984.

POGGI, V., ARCIONI, A., FILIPPINI, P., PIFFERI, P. G., 2000: Foliar application of selenite and selenate to potato (Solanum tuberosum): Effect of a ligand agent on selenium content of tubers. Journal of Agricultural and Food Chemistry, 48, 10: 4749-4751. ISSN 0021-8561. 
RANI, N., DHILLON, K. S., DHILLON, S. K., 2005: Critical levels of selenium in different crops grown in an alkaline silty loam soil treated with selenite-Se. Plant and Soil, 277, 1-2: 367-374. ISSN 0032-079X.

REILLY, C., 1998: Selenium: A new entrant into the functional food arena. Trends in Food Science and Technology, 9, 3: 114-118. ISSN 0924-2244.

TAN, J. A., ZHU, W., WANG, W., LI, R., HOU, S. WANG, D., YANG, L., 2002: Selenium in soil and endemic diseases in China. Science of the Total Environment, 284, 1-3: 227-235. ISSN 0048-9697.

TOLER, H. D., CHARRON, C. S., KOPSELL, D. A., SAMS, C. E., RANDLE, W. M., 2007: Selenium and sulfur increase sulfur uptake and regulate glucosi- nolate metabolism in Brassica oleracea. Acta Horticulturae, 744: 311-315. ISSN 0567-7572.

VINAY-SINGH, MALIK, R. S., 1990: Effect of phosphorus, sulphur and selenium on growth, their contents and utilisation by berseem. Legume Research, 13, 3: 123-126. ISSN 0250-5371.

WHITE, P. J., BOWEN, H. C., PARMAGURU, P., FRITZ, M., SPRACKLEN, W. P., SPIBY, R. E., MEACHAM, M. C., MEAD, A., HARRIMAN, M., TRUEMAN, L. J., SMITH, B. M., THOMAS, B., BROADLEY, M. R., 2004: Interactions between selenium and sulphur nutrition in Arabidopsis thaliana. Journal of Experimental Botany, 55, 404: 1927-1937. ISSN 0022-0957.

Ing. Lubica Zemková, Prof. Ing. Jaroslav Hlušek, CSc., Ing. Tomáš Lošák, Ph.D., Ústav agrochemie, půdoznalství, mikrobiologie a výživy rostlin, Doc. Ing. Miroslav Jůzl, CSc., Ing. Petr Elzner, Ústav pěstování, šlechtění rostlin a rostlinolékařství, Mendelova zemědělská a lesnická univerzita v Brně, Zemědělská 1, 61300 Brno, Česká republika, e-mail: xzemkova@node.mendelu.cz, hlusek@mendelu.cz, losak@mendelu.cz, juzl@ mendelu.cz,xelzner@node.mendelu.cz 
